\title{
PENGEMBANGAN INSTRUMEN PENILAIAN KETERAMPILAN BERPIKIR KRITIS SISWA SMA PADA MATERI SISTEM PENCERNAAN
}

\author{
Oktaviani Dwi Putri ${ }^{1}$ \\ Nevrita $^{2}$ \\ Nur Eka Kusuma Hindrasti ${ }^{3}$ \\ 1,23 \\ Program Studi Pendidikan Biologi, Universitas Maritim Raja Ali Haji \\ Email: nurekakh2017@u mrah.ac.id
}

\begin{abstract}
One of the skills that must be mastered by students in the 21 st century is critical thinking skills. These skills are still low in students in Indonesia, so there needs to be an effort to improve them. Developing instruments for assessing critical thinking skills can optimize assessment for learning functions. Preliminary research conducted at one of the high schools in Tanjungpinang found that the assessment instruments used were not oriented towards critical thinking skills. The purpose of this study is to develop a valid and reliable instrument for assessing critical thinking skills. This type of research is Research and Development. Product development procedures through 3 stages of research, namely introduction, design, and development. The preliminary stage consists of field studies and literature studies. The design phase consists of designing research products and research instruments. The development stage is theoretical validation (by experts) and empirical validation. The results of the study show that the instruments developed refer to the aspects and indicators of critical thinking skills by Ennis (2015). The assessment instruments developed in this study were declared valid with quite high validity and reliability with high reliability
\end{abstract}

Kata Kunci: instrumen penilaian, keterampilan berpikir kritis, sistem pencernaan

\section{PENDAHULUAN}

Penilaian merupakan proses pengumpulan data yang menunjukkan perkembangan belajar peserta didik. Penilaian harus didasarkan pada kurikulum yang berlaku (Sudjana, 2013; Mardapi, 2016). Penyempurnaan kurikulum 2013 terus dilakukan, hingga sejak Tahun 2016 dikenal dengan nama Kurikulum Nasional (Farida, 2017). Orientasi kurikulum nasional diterjemahkan dalam praktik pendidikan dengan tujuan khusus agar peserta didik memiliki kompetensi yang diperlukan bagi kehidupan masyarakat di masa kini dan di masa mendatang. Saat ini kita berada pada abad 21 yang ditandai dengan perkembangan teknologi yang pesat, sehingga sains dan teknologi merupakan salah satu landasan penting dalam pembangunan bangsa. Kompetensi yang harus dikuasai peserta didik di abad 21 antara lain: keterampilan belajar dan berinovasi yang meliputi berpikir kritis dan mampu menyelesaikan masalah, kreatif dan inovatif, serta mampu berkomunikasi dan berkolaborasi; 2) terampil untuk 
menggunakan media, teknologi, informasi dan komunikasi (TIK); 3) kemampuan untuk menjalani kehidupan dan karir, meliputi kemampuan beradaptasi, luwes, berinisiatif, mampu mengembangkan diri, memiliki kemampuan sosial dan budaya, produktif, dapat dipercaya, memiliki jiwa kepemimpinan, dan tanggung jawab (Kemendikbud, 2016).

Keterampilan berpikir kritis merupakan salah satu keterampilan yang penting dimiliki manusia yang hidup di abad 21. Hal tersebut sejalan dengan SKL (standar kompetensi lulusan) siswa yang belajar Biologi di SMA/MA yang pertama yaitu : menjalani kehidupan dengan sikap positif dengan daya pikir kritis, kreatif, inovatif, dan kolaboratif, disertai kejujuran dan keterbukaan, berdasarkan potensi proses dan produk biologi (Kemendikbud, 2016). Dengan demikian guru-guru khususnya guru Biologi hendaknya melakukan pembelajaran yang mengembangkan keterampilan berpikir tingkat rendah ke pembelajaran yang mengembangkan keterampilan berpikir tingkat tinggi, salah satunya adalah keterampilan berpikir kritis. Keterampilan berpikir kritis dimaknai sebagai kemampuan untuk berpikir reflektif yang rasional dan terfokus pada keputusan yang harus diambil untuk diyakini ataupun dilakukan (Ennis, 2015). Walker (2005) dalam Fakhriyah (2014) menyatakan bahwa keterampilan berpikir kritis merupakan suatu proses yang memungkinkan siswa membangun pengetahuan melalui pemecahan masalah dan kolaborasi. Orang yang memiliki keterampilan berpikir kritis adalah orang yang mampu mengambil keputusan secara tepat, cepat, dan bertanggung jawab, dan mampu menghindari diri dari penipuan, indoktrinasi, dan pencucian otak (Liqman, 2003 dalam Redhana, 2012). Implementasi penilaian keterampilan berpikir kritis secara umum masih sangat rendah, yaitu sekitar 45\% (Lane, 2016). Hal tersebut dapat disebabkan oleh kecenderungankecenderungan dalam pelaksanaannya, yaitu membutuhkan waktu yang lebih lama dari pada penilaian standar yang telah ditetapkan (Huber dan Kuncel, 2016). Instrumen penilaian yang dirancang dengan baik dan sesuai dengan tingkatan kemampuan berpikir dapat meningkatkan daya berpikir siswa, khususnya berpikir kritis (Amalia, 2014). Implementasi penilaian keterampilan berpikir kritis yang rendah berdampak keterampilan berpikir kritis dan kreatif lulusan pada sekolah dasar sampai dengan perguruan tinggi di Indonesia yang rendah (Reta, 2012). Seyogyanya keterampilan berpikir kritis penting dilatihkan karena keterampilan berpikir ini tidak dibawa sejak lahir (Redhana dan Liliasari, 2008).

Penerapan penilaian keterampilan berpikir krtis sering dilakukan sengan tes esai (uraian). Hal ini sesuai dengan konsep berpikir kirits (Ennis, 1985 dalam Saputri, 2018) bahwa dalam pelaksanaan tes perlu ada keterlibatan mental, strategi, dan representasi yang digunakan untuk memecahkan masalah, membuat keputusan, dan mempelajari konsepkonsep baru. Mengembangkan instrumen penilaian keterampilan 
berpikir kritis dapat mengoptimalkan fungsi assesment for learning, yaitu penilaian untuk pembelajaran (Wulan, 2018). Penilaian juga hendaknya berfungsi untuk pembelajaran, artinya ketika siswa mengerjakan suatu soal atau tugas, dengan sendirinya siswa juga sedang belajar. Dalam hal ini siswa juga belajar mengembangkan keterampilan berpikir kritis dalam menghadapi permasalah-permasalahan terkait konsep sistem pencernaan. Ketika siswa terbiasa dengan soal keterampilan berpikir kritis, diharapkan siswa mampu menghadapi dan menyelesaikan permasalahan kehidupan nyata. Tes yang digunakan untuk mengukur keterampilan berpikir kritis dalam pelajaran Biologi merupakan bentuk pelatihan dalam menghadapi dan menyelesaikan permasalahan dalam kehidupan seharihari (Palm, 2008 dalam Wulan, 2018).

Materi sistem pencernaan merupakan salah satu materi mata pelajaran Biologi yang bersifat abstrak karena siswa tidak dapat secara langsung melihat penampakan sel, jaringan, dan organ yang membangun sistem pencernaan, serta tidak dapat mengetahui jalannya proses sistem pencernaan. Sehingga ketika diskusi pada saat pembelajaran, siswa cenderung mengajukan pertanyaan terkait penyakit dan fenomena dalam kehidupan sehari-hari yang berhubungan dengan sistem pencernaan. Mengajarkan sistem pencernaan hendaknya menggunakan pendekatan pembelajaran yang kontekstual. Sebagaimana yang diteliti oleh Widarti (2013) menyatakan bahwa pembelajaran dengan pendekatan CTL (Contextual Teaching Learning) berpengaruh positif terhadap aktivitas dan hasil belajaar siswa pada materi sistem pencernaan. Begitu juga penilaian untuk materi sistem pencernaan sebaiknya juga kontekstual. Soal untuk mengukur HOTS (Higher Order Thinking Skills) atau keterampilan berpikir tingkat tinggi, yang meliputi berpikir kritis, memiliki ciri kontekstual dengan kehidupan seharihari (Widana, 2017). Artikel ini membahas bagaimana instrumen penilaian keterampilan berpikir kritis dikembangkan dengan memperhatikan prinsip-prinsip sesuai kharakteristik yang ada.

\section{METODE}

Jenis penelitian Research and Development (R\&D) yaitu pengembangan instrumen penilaian keterampilan berpikir kritis. Jenis Research and Development (R\&D) yang digunakan mengacu pada Sugiyono (2010) yang diadaptasi sesuai dengan kebutuhan penelitian. Waktu penelitian dilaksanakan dari Bulan Desember 2018 sampai dengan Januari 2019. Adapun alur penelitian yang dilakukan adalah pada Gambar 1. 
Tahap Pendahuluan

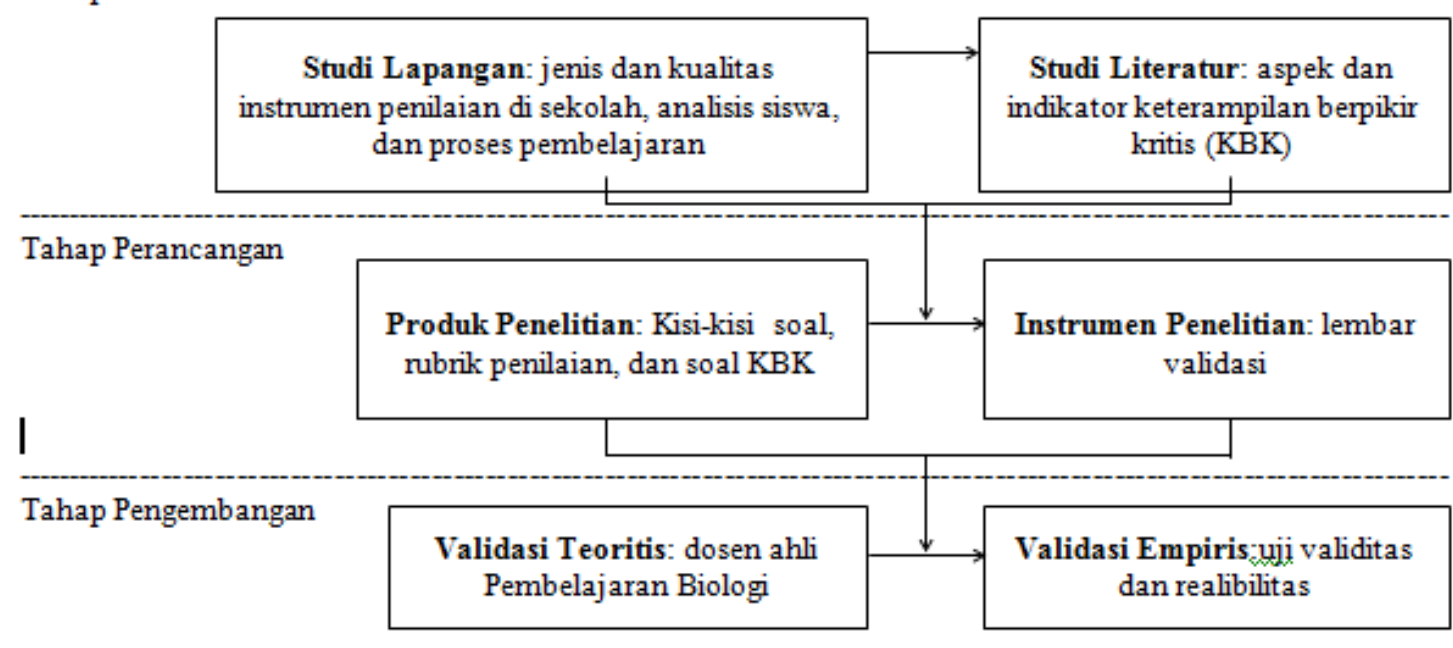

Gambar 1 Alur Penelitian

Tahap penelitian dibagi menjadi tiga tahap yaitu tahap pendahuluan, tahap perancangan, dan tahap pengembangan. Tahap pendahuluan meliputi dua tahapan yaitu: 1) studi lapangan, yang dilakukan untuk mendapat informasi berupa jenis dan kualitas instrumen penilaian pembelajaran Biologi yang digunakan di sekolah, karakter siswa, dan proses pembelajaran Biologi, dan 2) studi literatur dengan mencari referensi tentang kriteria pengembangan keterampilan berpikir kritis serta indikator keterampilan berpikir kritis.

Tahap perancangan yaitu penyusunan produk dan instrumen penelitian, produk penelitian yang dimaksud yaitu instrumen penilaian keterampilan berpikir kritis berupa soal esai dan lembar wawancara, sedangkan instrumen penelitian adalah lembar validasi. Tahap pengembangan yaitu melakukan validasi teoritis oleh pakar dan validasi empiris yaitu dengan mengujicobakan untuk mengetahui validitas dan realibilitas. Pakar yang dimaksud dalam validasi expert atau oleh pakar adalah dua orang dosen dan satu orang guru sebagai praktisi lapangan.

Desain instrumen penilaian diawali dengan menyusun kisi-kisi soal berdasarkan data pada tahap pendahuluan, menyusun soal berdasarkan kisi-kisi, dan menyusun kunci jawaban. Instrumen penilaian keterampilan berpikir kritis yang dikembangkan adalah berupa tes atau soal esai menggunakan aspek indikator berpikir kritis menurut Ennis (2015) yaitu 1) basic clarification, 2) bases for decision, 3) inference, 4) advanced clarification, and 5) strategies and tactics. Instrumen penilaian mengalami beberapa kali revisi. Selanjutnya, uji coba empiris dilakukan untuk mengetahui validitas soal tes yaitu dengan teknik korelasi product moment pearson dan reliabilitas soal tes menggunakan rumus Cronbach - Alfa $(\alpha)$.

\section{HASIL DAN PEMBAHASAN}

Pengembangan instrumen penilaian keterampilan berpikir kritis yang dilakukan mengacu pada model pengembangan sugiyono (2010) yang 
terdiri dari (1) pendefinisian dengan melakukan studi pendahuluan yang meliputi studi lapangan dan studi literatur, (2) desain produk diawali dengan menyusun kisi-kisi soal, soal tes berupa esai, dan lembar validasi desain, (3) pengembangan dimulai dari tahap validasi teoritis oleh pakar berupa validasi isi dan konstruk dan validasi empiris yaitu dengan mengujicobakan untuk mengetahui validitas dan realibilitas, implementasi, merupakan tahapan terakhir sebelum produk disebarluaskan. Namun pada penelitian ini dilakukan sampai tahap ketiga, karena keterbatasan waktu penelitian.

\section{Tahap Pendahuluan}

Studi lapangan pada tahap pendahuluan dilakukan di beberapa SMA di Tanjungpinang pada Tahun Ajaran 2018-2019, didapatkan data tentang jenis instrumen penilaian pembelajaran Biologi tepatnya materi sistem pencernaan di sekolah, yaitu pilihan ganda dan esai yang mengukur proses kognitif pada tingkatan $\mathrm{C} 1$ (hafalan) dan C2 (pemahaman), kadang C3. Proses kognitif pada jenjang $\mathrm{C} 1$ sampai dengan $\mathrm{C} 3$ dikategorikan ke dalam LOTS (Lower Order Thinking Skills) atau keterampilan berpikir tingkat rendah (Anderson and Krathwohl, 2010). Padahal menurut Widana (2017) keterampilan berpikir kritis termasuk ke dalam HOTS. Artinya, kondisi mengenai instrumen penilaian pembelajaran materi sistem pencernaan di sekolah tersebut kurang mampu melatih keterampilan berpikir kritis siswa (Amalia, 2014). Jenis soal yang mengukur LOTS tidak melatihkan keterampilan berpikir kritis siswa (Pursitasari dan Permanasari, 2012). Instrumen penilaian pembelajaran yang dapat melatih keterampilan berpikir kritis siswa menjadi penting untuk dikembangkan dengan tujuan: agar HOTS siswa meningkat sehingga dapat menghadapi tuntutan kemajuan ilmu pengetahuan dan teknologi (Amalia, 2014), dan agar siswa mampu survive di abad ke-21 (Wijayanti dkk, 2016; Kemendikbud, 2016). Selain mengembangkan strategi pembelajaran untuk melatih keterampilan berpikir kritis, instrumen penilaian juga dapat dikembangkan untuk mengoptimalkan fungsi assesment for learning (penilaian untuk pembelajaran). Assesment for learning diartikan sebagai penilaian untuk pembelajaran (Wulan, 2018), yang menyediakan informasi bagi peserta didik tentang belajar mereka.

Berdasarkan wawancara terhadap guru didapatkan hasil bahwa instrumen penilaian harus lengkap, tidak hanya soal namun juga mencakup kisi-kisi soal, soal, dan rubrik penilaian. Kisi-kisi soal digunakan untuk menganalisis kemampuan atau keterampilan siswa pada setiap aspeknya. Ketika seorang siswa kurang dalam sebuah aspek, maka guru dapat melakukan upaya untuk meningkatkannya. Rubrik penilaian atau pedoman penskoran berguna untuk menentukan skor yang kemudian dikonversi menjadi nilai berdasarkan kriteria tertentu. Hal tersebut sesuai dengan yang disyaratkan oleh Mukti (2018), bahwa dalam mengembangkan insrumen 
penilaian khususnya berpikir kritis harus lengkap mencakup penyusunan kisi-kisi, penyusunan pedoman penskoran, validasi isi, dan perbaikan butir.

Studi lapangan juga dilakukan untuk mengetahui karakter siswa. Berdasarkan perkembangan kognitif menurut Piaget (Suparno, 2001 dalam Farida, 2017), maka siswa SMA adalah pada tahap operasional formal. Ciri pokok perkembangan pada tahap ini adalah anak sudah mampu berpikir abstrak dan logis, mampu menarik kesimpulan, menafsirkan, dan mengembangkan hipotesis. Karakter siswa SMA tersebut sesuai dengan aspek-aspek berpikir kritis menurut Ennis (2015). Terkait dengan jenis soal yang dikerjakan oleh siswa, siswa cenderung tidak suka soal esai yang terlalu banyak (lebih dari 15 butir), karena akan membosankan. Selain itu siswa juga cenderung menyukai soal yang kontekstual sesuai dengan kehidupan sehari-hari. Studi lapangan mengenai karakter siswa ini berguna dalam mengembangkan soal penilaian keterampilan berpikir kritis siswa SMA, terkait jenis soal, jumlah butir soal, dan tingkat kognitif butir soal.

Pembelajaran Biologi yang telah diobservasi saat studi lapangan menunjukkan bahwa pembelajaran Biologi diajarkan sesuai KI dan KD pada kurikulum Biologi SMA Tahun 2016. Dalam melakukan penilaian terhadap satu KD (Kompetensi Dasar), waktu yang dibutuhkan adalah 45 menit (satu jam pelajaran). Untuk memfokuskan perhatian siswa pada suatu hal yang dianggap penting, guru biasanya memberikan penekanan lebih. Contohnya, terkait wacana yang diberikan di awal pembelajaran sebagai bahan observasi, maka guru menebalkan kalimat yang dianggap penting ataupun inti dari wacana tersebut.

Tinjauan dari penelitianpenelitian yang relevan didapatkan peneliti dari artikel di jurnal-jurnal, buku-buku dan prosiding-prosiding. Penelitian oleh Amalia (2014) tentang pengembangan instrumen penilaian keterampilan berpikir kritis siswa SMA pada materi asam basa menggunakan model R\&D mengacu pada Sugiyono dan menghasilkan instrumen berupa tes esai analisis, lembar aktivitas siswa, dan tes problem solving. Saputri dkk. (2018) melakukan penelitian tentang profil keterampilan berpikir kritis dengan indikator menurut Facione yang meliputi interpretation, analysis, evaluation, explanation, conclusion, and self-regulation. Fakhriyah (2014) mengembangkan kemampuan berpikir kritis mahasiswa dengan indikator yang diadaptasi dari Ennis (2015) yaitu kemampuan mengidentifikasi, menganalisis, memecahkan masalah secara kreatif, kemampuan dalam menentukan solusi yang tepat dalam memecahkan masalah, kemampuan bertanya atau mengkritisi permasalahan dari kelompok lain, dan kemampuan menjawab dan pertanyaan dan mengemukakan pendapat.

$$
\text { Kajian literatur dilakukan }
$$
untuk mengetahui definisi berpikir kritis, aspek-aspek berpikir kritis, cara mengembangkan dan mengukur keterampilan berpikir kritis. Berdasarkan kajian literatur yang dilakukan, berpikir kritis yang dibatasi pada penelitian ini adalah berpikir 
kritis menurut Ennis (2015) yang terbaru. Berpikir kritis didefiniskan sebagai keterampilan berpikir secara beralasan dan reflektif terhadap apa yang diyakini dan dilakukan. Berdasarkan definisi tersebut, berpikir kritis terdiri dari 5 (lima) aspek yaitu 1) klarifikasi dasar (basic clarification) yang meliputi 4 (empat) indikator yaitu a) fokus terhadap sebuah pertanyaan (focus on a question), b) menganalisis argumen (analyze arguments), c) bertanya dan menjawab pertanyaan klarifikasi (ask and answer clarification questions), serta d) memahami dan menggunakan grafik dan matematika dasar (understand and use elementary graphs and math); 2) dasar mengambil sebuah keputusan (bases for a decision), yang meliputi 3 (tiga) indikator yaitu a) mempertimbangkan kredibilitas suatu sumber (Judge the credibility of a source), b) mengobservasi dan menilai laporan observasi (Observe, and judge observation reports), c) menggunakan pengetahuan yang ada (Use existing knowledge); 3) menyimpulkan (inference), yang meiputi 3 indikator yaitu a) menyimpulkan dan mempertimbangkan kesimpulan (Deduce, and judge deductions), b) membuat dan mempertimbangkan argumen dan kesimpulan induktif (Make, and judge inductive inferences and arguments), dan c) membuat dan mempertimbangkan penilaian (Make, and judge value judgment); 4) klarifikasi lanjutan (advanced clarification) yang meliputi 7 indikator yaitu a) menentukan istilah dan mempertimbangkan definisi (Define terms, and judge definition ), b) menangani dalih yang tepat (Handle equivocation appropriately), c) menghubungkan dan menilai asumsi yang tidak disebutkan (Attribute and judge unstated assumptions), d) mempertimbangkan (Think suppositionally), e) menangani pendapat yang keliru (Deal with fallacy label), f) berhati-hati, dan memeriksa kualitas pemikiran mereka sendiri (Be aware of, and check the quality of, their own thinking), dan $g$ ) menangani hal-hal secara tertib (Deal with things in an orderly manner); 5) Strategi dan taktik (Strategies and tactics): tidak konstitutif, tetapi sering membantu jika tidak disalahgunakan (Not Constitutive, But Often Helpful If Not Misused) yang meliputi 2 indikator yaitu a) menggunakan strategi retoris (Employ rhetorical strategies), dan b) berurusan dengan strategi retoris (Deal with rhetorical strategies).

\section{Tahap Perancangan}

Studi pada tahap pendahuluan diperlukan untuk melakukan tahap perancangan. Tahap perancangan dimulai dengan menyusun kisi-kisi soal. Kisi-kisi soal terdiri dari identitas yang meliputi jenjang sekolah, mata pelajaran, kelas/semester, dan kisi-kisi itu sendiri yang berupa tabel. Soal keterampilan berpikir kritis berupa tes esai dengan kisi-kisi sebagai berikut: 
O.D. PUTRI, NEVRITA, \& N. E. K. HINDRASTI, PENGEMBANGAN....

Tabel 1. Kisi-kisi test keterampilan berpikir kritis siswa

\begin{tabular}{|c|c|c|c|c|c|}
\hline No & $\begin{array}{l}\text { Aspek } \\
\text { Kete rampilan } \\
\text { Berpikir } \\
\text { Kritis }\end{array}$ & $\begin{array}{l}\text { Indikator } \\
\text { Kemampuan } \\
\text { Berpikir Kritis }\end{array}$ & $\begin{array}{lr}\text { Rincian } & \text { Indikator } \\
\text { Kemampuan Berpikir Kritis }\end{array}$ & $\begin{array}{l}\text { Jenjang } \\
\text { Kognitif }\end{array}$ & $\begin{array}{l}\text { No } \\
\text { Soal }\end{array}$ \\
\hline \multirow[t]{5}{*}{1} & \multirow{5}{*}{$\begin{array}{l}\text { Basic } \\
\text { Clarification } \\
\text { (klarifikasi } \\
\text { dasar) }\end{array}$} & $\begin{array}{l}\text { Focus on } \quad \text { a } \\
\text { question } \\
\text { (fokus terhadap } \\
\text { sebuah pertanyaan) }\end{array}$ & $\begin{array}{lr}\text { Identify or formulate a } \\
\text { question } & \\
\text { (mengidentifikasi } & \text { atau } \\
\text { merumuskan } & \text { sebuah } \\
\text { permasalahan) } & \end{array}$ & $\mathrm{C} 4$ & 1 \\
\hline & & $\begin{array}{l}\text { Ask and answer } \\
\text { clarification } \\
\text { question } \\
\text { (bertanya dan } \\
\text { menjawab } \\
\text { pertanyaan } \\
\text { klarifikasi) }\end{array}$ & $\begin{array}{l}\text { a. Identify or formulate } \\
\text { criteria for judging possible } \\
\text { answer } \\
\text { (mengidentifikasi } \\
\text { merumuskan kriteria untuk } \\
\text { menilai } \\
\text { jawaban }\end{array}$ & & \\
\hline & & $\begin{array}{l}\text { Analyze arguments } \\
\text { (menganalis is } \\
\text { argumen) }\end{array}$ & 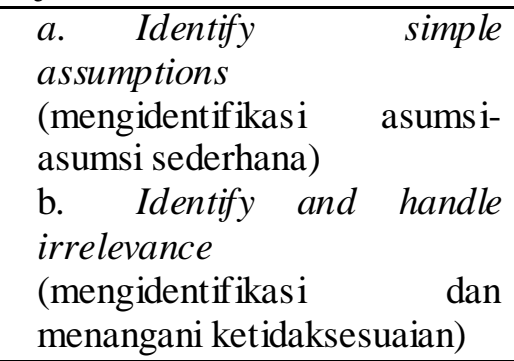 & $\mathrm{C} 4$ & 2 \\
\hline & & $\begin{array}{l}\text { Observe, and judge } \\
\text { observation reports } \\
\text { (mengamati dan } \\
\text { mempertimbangkan } \\
\text { laporan } \\
\text { pengamatan) }\end{array}$ & $\begin{array}{l}\text { a. Corroboration (bukti yang } \\
\text { menguatkan) }\end{array}$ & $\mathrm{C} 4$ & 4 \\
\hline & & $\begin{array}{l}\text { Use existing } \\
\text { knowledge } \\
\text { (menggunakan } \\
\text { pengetahuan yang } \\
\text { ada) }\end{array}$ & $\begin{array}{l}\text { a. Background knowledge } \\
\text { (latar belakang pengetahuan) } \\
\text { b. Their knowledge of the } \\
\text { situation } \\
\text { (pengetahuannya terkait } \\
\text { situasi) }\end{array}$ & C5 & 5 \\
\hline \multirow[t]{2}{*}{3} & & $\begin{array}{l}\text { Make and judge } \\
\text { inductive inferences } \\
\text { and arguments } \\
\text { (membuat dan } \\
\text { menilai kesimpulan } \\
\text { dan argumen } \\
\text { induktif) }\end{array}$ & $\begin{array}{l}\text { a. To generalizations } \\
\text { (untuk mengeneralisasi) }\end{array}$ & $\mathrm{C} 4$ & 6 \\
\hline & $\begin{array}{l}\text { Inference } \\
\text { (kesimpulan) }\end{array}$ & $\begin{array}{l}\text { Make and judge } \\
\text { value judgement } \\
\text { (membuat dan } \\
\text { mempertimbangkan } \\
\text { penilaian) }\end{array}$ & $\begin{array}{l}\text { a. Backgroundfacts } \\
\text { (latar belakang fakta) } \\
b \text {. Consequences of } \\
\text { accepting or rejecting the } \\
\text { judgement } \\
\text { (konsekuensi dari menerima } \\
\text { atau menolak keputusan) }\end{array}$ & $\mathrm{C} 5$ & 7 \\
\hline 4 & & $\begin{array}{l}\text { Define terms and } \\
\text { judge definitions }\end{array}$ & $\begin{array}{l}\text { a. Definitions form } \\
\text { (bentuk definisi) }\end{array}$ & C6 & 8 \\
\hline
\end{tabular}




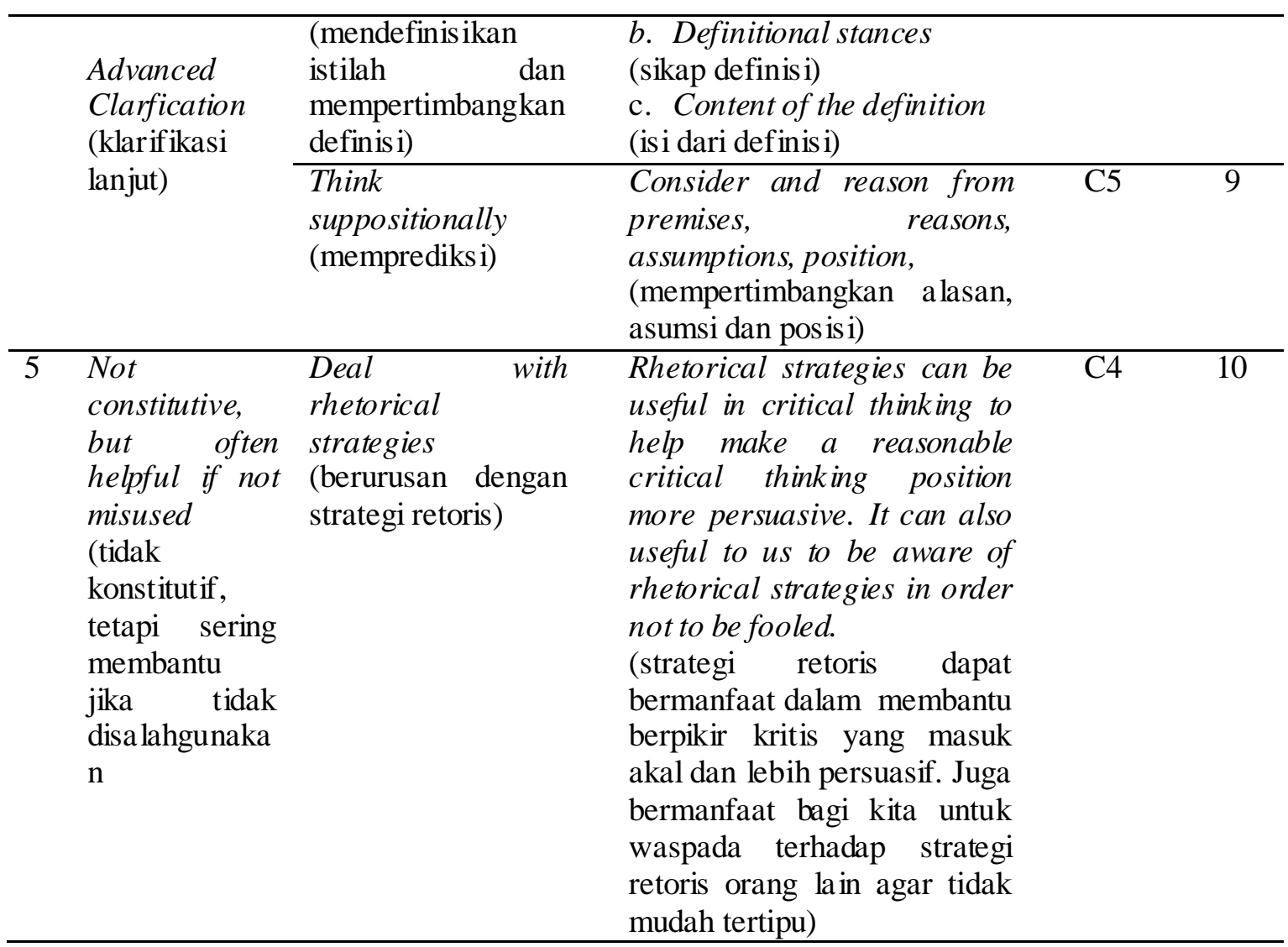

Kisi-kisi tersebut sesuai dengan prinsip penyusunan kisi-kisi menurut Farida (2017) dan Gantini dan Suhendar, 2017. Selanjutnya rubrik penilaian disusun berupa tabel yaitu terdiri dari nomor soal, skor, dan indikator. Skor setiap butir soal ditentukan dengan gradasi skor yaitu 0,1 , dan 2 ada juga yang sampai 3 . Dengan demikian skor maksimal yang diperoleh siswa pada setiap butir soal adalah 2 atau 3. Contoh indikator pada rubrik penilaian untuk soal nomor 2 yaitu siswa akan mendapatkan skor 2 jika mampu mengidentifikasi asumsi yang ada dengan menjelaskan ketidakrelevanan antara mitos dengan proses tersedak serta memberikan alasan yang logis, skor 1 jika mampu mengidentifikasi asumsi yang ada dengan menjelaskan ketidakrelevanan anatara mitos dengan proses tersedak namun tidak mampu memberikan alasan yang logis, serta skor 0 jika jawaban salah/tidak menjawab.

Soal keterampilan berpikir kritis dikembangkan berdasarkan kisikisi yang telah disusun. Soal terdiri dari tiga bagian yaitu identitas soal yang meliputi nama dan kelas, petunjuk pengerjaan soal, dan butir soal itu sendiri. Soal berjumlah 10 butir dengan bentuk tes uraian bebas. Soal dikembangkan berdasarkan prinsip-prinsip penyusunan tes esai yaitu: 1) Butir soal uraian bebas menuntut jawaban siswa yang sangat terbuka dan siswa bebas menuangkan pemikiran, keluasan pengetahuannya dan mengungkapkannya dalam bentuk tulisan dan karangan (Farida, 2017); 2) pertanyaan mengarah pada jawaban yang jelas, sehingga para ahli dapat setuju bahwa satu jawaban akan lebih baik daripada yang lainnya; 3) 
sebaiknya pertanyaan diawali dengan kata-kata seperti "Bandingkan ...", "Berikan alasan ...", "Jelaskan mengapa ...", “ Beri contoh ...", “ dan semacamnya; dan 4) tidak memberikan kesempatan siswa untuk memilih dan menjawab hanya sebagian di antara nomor pertanyaan yang disediakan, karena dapat merendahkan reliabilitas tes, dan 5) tidak menanyakan sikap. Selain itu, penulis juga menganggap penting bahwa dalam menyusun soal keterampilan berpikir kritis, soal harus mengungkap kemampuan argumentasi siswa. Siswa harus memiliki kemampuan berargumentasi yang baik untuk mengembangkan keterampilan berpikir kritis. Kemampuan argumentasi yang dimaksud adalah kemampuan menyatakan atau menjawab (claim), memberikan alas an atas jawaban (reason), dan memberikan bukti yang mendukung alasan (evidence).

Sebelum dilakukan validasi soal, dibuat lembar validasi soal. Lembar validasi soal memuat judul, identitas validator, petunjuk, dan kolom ceklis, ruang saran, dan pengesahan validator. Selain itu juga disusun surat keterangan validasi instrumen soal berpikir kritis. Validasi terdiri dari dua yaitu validasi isi dan validasi konstruk. Validasi isi untuk memvalidasi atau mengecek kesesuaian butir soal dengan indikator keterampilan berpikir kritis menurut Ennis (2015). Sedangkan validasi konstruk untuk memvalidasi atau mengecek 1) struktur kalimat pertanyaan apakah sudah sesuai dengan Ejaan Berbahasa (EB) atau belum, 2) kesesuaian jenjang kognitif yang digunakan, dan 3) kesesuaian kisi-kisi soal dengan butir pertanyaan. Instrumen keterampilan berpikir hendaknya memiliki validitas konstruk yang baik sebelum instrumen tersebut digunakan (Docktor \& Heller, 2009). Setiap butir soal dicek validasi isi dan konstruknya, dengan memberikan 3 kriteria penilaian yaitu sesuai, kurang sesuai, dan tidak sesuai.

\section{Tahap Penge mbangan}

Tahap selanjutnya adalah tahap pengembangan. Dalam tahap ini dilakukan validasi teoritis oleh pakar dan validasi empiris yaitu dengan mengujicobakan soal untuk mengetahui validitas dan realibilitas. Farida (2017) menyebutkan validitas teoritis ini dengan istilah analisis instrumen secara kualitatif. Pakar yang dimaksud dalam validasi expert atau oleh pakar adalah dua orang dosen yang ahli pembelajaran Biologi. Validasi pakar menjadi bagian yang penting untuk memulai pengembangan (Amalia, 2014). Hasil validasi dosen yang pertama adalah seluruh validasi isi dan konstruk pada kriteria sesuai, dan saran yang diberikan adalah kata yang salah tulis diperbaiki sesuai EB. Sedangkan hasil validasi dosen yang kedua adalah seluruh validasi isi dan konstruk pada kriteria sesuai, dan saran yang diberikan adalah hedaknya pertanyaan mengarah pada jawaban pasti yang tidak bersifat fifty-fifty.

Setelah divalidasi oleh ahli, soal divalidasi empiris dengan mengujicobakan terhadap 33 siswa kelas XII jurusan MIPA. Validasi empiris dilakukan untuk mengetahui validitas dan reliabilitas butir soal. Sebuah item soal dikatakan valid jika 
mempunyai dukungan yang besar terhadap skor total. Skor pada item menyebabkan skor total menjadi tinggi atau rendah (Arikunto, 2012). Validitas dicari dengan teknik korelasi product moment pearson (Farida, 2017). Tafsiran harga koefisien korelasi yaitu $0,80-1,0$ ditafsirkan korelasi sangat tinggi; $0,60-0,79$ ditafsirkan korelasi tinggi; 0,40-0,59 ditafsirkan korelasi cukup; 0,20-0,39 ditafsirkan korelasi rendah, dan 0,000,19 ditafsirkan korelasi sangat rendah. Sedaangkan reliabilitas adalah tingkat keajegan (konsistensi) suatu tes, yakni sejauh mana suatu terdapat dipercaya untuk menghasilkan skor yang konsisten atau tidak berubah (Arikunto, 2008). Rumus yang digunakan menghitung reliabilitas tes esai adalah rumus Cronbach - Alfa $(\alpha)$ (Arikunto, 2012). Kriteria reliabilitas soal adalah 0,81-1,00 dikategorikan sangat tinggi; 0,61-0,80 dikategorikan tinggi; 0,41-0,60 dikategorikan cukup; 0,21-0,40 dikategorikan rendah; dan 0,20-1,00 dikategorikan sangat rendah.

Berdasarkan uji coba yang dilakukan diperoleh hasil validitas tabel 2 .

Tabe12. Hasil Validitas Instrumen

\begin{tabular}{lccll}
\hline $\begin{array}{c}\text { No } \\
\text { Item }\end{array}$ & $\begin{array}{c}\text { r } \\
\text { tabel }\end{array}$ & $\begin{array}{c}\text { r } \\
\text { hitung }\end{array}$ & Kategori & Keputusan \\
\hline 1 & 0.344 & 0.727 & Tinggi & Valid \\
2 & 0.344 & 0.452 & $\begin{array}{l}\text { Cukup } \\
\text { Tinggi }\end{array}$ & Valid \\
& & & $\begin{array}{l}\text { Cukup } \\
\text { Tinggi }\end{array}$ & Valid \\
3 & 0.344 & 0.554 & Rendah & Valid \\
& & & $\begin{array}{l}\text { Cukup } \\
\text { Tinggi }\end{array}$ & Valid \\
5 & 0.344 & 0.347 & Cukup & Valid \\
6 & 0.344 & 0.595 & Tinggi &
\end{tabular}

$\begin{array}{lllll}7 & 0.344 & 0.433 & \begin{array}{l}\text { Cukup } \\ \text { Tinggi }\end{array} & \text { Valid } \\ 8 & 0.344 & 0.582 & \begin{array}{l}\text { Cukup } \\ \text { Tinggi }\end{array} & \text { Valid } \\ 9 & 0.344 & 0.611 & \begin{array}{l}\text { Tinggi } \\ \text { Cukup }\end{array} & \text { Valid } \\ 10 & 0.344 & 0.508 & \begin{array}{l}\text { Valid } \\ \text { Tinggi }\end{array} & \end{array}$

Dengan demikian dapat diambil kesimpulan bahwa validitas butir soal didominasi oleh kriteria cukup tinggi. Walaupun ada soal nomor 4 (empat) yang memiliki validitas rendah. Tidak lanjut dari soal yang memiliki validitas rendah tersebut adalah dengan memperbaiki struktur dan isi butir pertanyaan. Sedangkan hasil reliabiltas menunjukkan bahwa koefisien reliabilitas Alpha adalah 0,705 dan dikategorikan tinggi. Keputusan terhadap reliabilitas soal berdasarkan skor koefisien yang didapat adalah soal dinyatakan reliabel. Walaupun menurut Azwar (1996) dalam Amalia (2014) kesepakatan informal menghendaki bahwa koefisien reliabilitas haruslah setinggi mungkin, biasanya sekitar 0,900. Instrumen keterampilan berpikir, tidak hanya menekankan pada LOTS, tetapi lebih pada HOTS, sehingga memiliki keajegan (reliabilitas) yang relatif rendah (Docktor \& Heller, 2009).

Kelemahan

dari pengembangan soal keterampilan berpikir kritis ini adalah penyusunan kisi-kisi kurang memperhatikan dimensi pengetahuan dan kompetensi dasar yang tercantum dalam silabus mata pelajaran Biologi SMA/MA Kurikulum 2013 (Kemendikbud, 2016). Dimensi pengetahuan dinyatakan dalam KI-3 (Kompetensi Inti) silabus tersebut. Kompetensi Inti yang terkait sistem pencernaan pada 
silabus tersebut adalah mata pelajaran biologi kelas XI yang berbunyi memahami, menerapkan, dan menganalisis pengetahuan faktual, konseptual, prosedural, dan metakognitif berdasar-kan rasa ingin tahunya tentang ilmu pengetahuan, teknologi, seni, budaya, dan humaniora dengan wawasan kemanusiaan, kebangsaan, kenegaraan, dan peradaban terkait penyebab fenomena dan kejadian, serta menerapkan pengetahuan prosedural pada bidang kajian yang spesifik sesuai dengan bakat dan minat-nya untuk memecahkan masalah. Kisi-kisi soal keterampilan berpikir kritis yang sudah disusun tidak ada komponen dimensi pengetahuan. Penilaian dengan memperhatikan dimensi pengetahuan penting dilakukan dengan tujuan memenuhi ketercapaian KI. Perubahan dalam standar penilaian pendidikan pada kurikulum 2013 salah satunya adalah penilaian tidak hanya pada level KD, tetapi juga KI (Farida, 2017).

Kompetensi dasar mengenai sistem pencernaan pada silabus tersebut adalah mata pelajaran biologi kelas XI nomor 3.8 yang berbunyi Menganalis is hubungan antara struktur jaringan penyusun organ pada sistem pencernaan dan mengaitkannya dengan bioprosesnya sehingga dapat menjelaskan proses pencernaan serta gangguan fungsi yang mungkin terjadi pada sistem pencernaan manusia melalui studi literatur, pengamatan, percobaan, dan simulasi. Soal keterampilan berpikir kritis yang sudah disusun lebih mengutamakan ketercapaian aspek dan indikator dari berpikir kritis, sedangkan terkait materi sistem pencernaan yang diklaim hanya sebatas mengenai pencernaan, tidak spesifik diturunkan dari indikator pembelajaran yang merupakan turunan dari kompetensi dasar. Padahal jika soal dikembangkan dengan memperhatikan secara seimbang antara ketercapaian aspek berpikir kritis dan juga kompetensi dasar sesuai kurikulum 2013 maka akan lebih bermanfaat bagi guru. Guru dapat menggunakan soal untuk menguji kompetensi 3.8 kelas XI.

\section{KESIMPULAN}

Instrumen

penilaian

pembelajaran Biologi yang digunakan kurang berorientasi pada keterampilan berpikir kritis. Pengembangan instrumen penilaian keterampilan berpikir kritis penting dilakukan untuk menumbuhkembangkan keterampilan berpikir kritis siswa. Prosedur pengembangan instrumen melalui 3 tahapan penelitian yaitu pendahuluan, perancangan, dan pengembangan. Instrumen yang digunakan adalah tes esai yang dikembangkan mengacu pada aspek dan indikator keterampilan berpikir kritis. Instrumen penilaian yang dikembangkan dalam penelitian ini dinyatakan valid dengan validitas cukup tinggi dan reliable dengan realibilitas tinggi.

\section{SARAN}

Penulis memberikan saran agar pengembangan instrumen penilaian atau tes keterampilan berpikir kritis selanjutnya tidak hanya memperhatikan ketercapaian aspek berpikir kritis, tetapi juga memperhatikan Kompetensi Dasar pada silabus kurikulum 2013. 


\section{DAFTAR RUJUKAN}

Anderson, L.W. \& Krathwohl, D.R. 2010. Kerangka Landasan untuk Pembelajaran, Pengajaran, dan Asesmen: Revisis Taksonomi Pendidikan Bloom. Yogyakarta: Pustaka Pelajar.

Amalia, N. F. \& Susilaningsih, E. 2014. Pengembangan Instrumen Penilaian Keterampilan Berpikir Kritis Siswa SMA pada Materi Sistem Pencernaan. Jurnal Inovasi Pendidikan Kimia, VIII(2): 1380-1389.

Arikunto, S. 2012. Dasar-dasar Evaluasi Pendidikan. Jakarta: Bumi Aksara.

Docktor, J. \& Heller, K. 2009. Robust Assessment Instrument for Student Problem Solving, Prosiding the NARST 2009 Annual Meeting, Minnesota university.

Ennis, R. H. 2015. Critical Thinking Assessment. Taylor and Francis. 32 (3) hal.179-186.

Fakhriyah, F. 2014. Penerapan Problem Based Learning dalam Upaya Mengembangkan Kemampuan Berpikir Kritis Mahasiswa. JPII. 3 (1): 95-101.

Farida, I. 2017. Evaluasi Pembelajaran Berdasarkan Kurikulum Nasional. Bandung: PT Remaja Rosdakarya.

Gantini, P. dan Suhendar, D. 2017. Penilaian Hasil Belajar. Bandung: Esensi.

Huber, C.H. \& N.R. Kuncel. 2016. Does College Teach Critical Thinking? A Meta-Analysis. Review of Educational Research, 86 (20): 431-468.
Kemendikbud. 2016. Silabus Sekolah Menengah Atas/ Madrasah Aliyah Mata Pelajaran Biologi. Jakarta: Kemendikbud.

Lane, D. \& Oswald, F. L. 2016. Do $45 \%$ of College Students Lack Critical Thinking Skills? Revisiting a Central Conclusion of Academicalli Adrif. Educational Measurement: Issues and Practice Fall, 35 (3): 23-25.

Mardapi, D. 2016. Pengukuran, Penilaian, dan Evaluasi Pendidikan. Yogyakarta: Nuha Medika.

Mukti, T. S. \& Istiyono, E. 2018. Instrumen Penilaian Kemampuan berpikir Kritis Peserta Didik SMA Negeri Mata Pelajaran Biologi Kelas X. Bioedukasi: Kurnal Pendiidkan Biologi, 11 (2): 105-110.

Pursitasari, I. D. \& Permanasari, A. 2012, Analisis Pemahaman Konsep dan Kesulitan Mahasis wa untuk Pengembangan Program Perkuliahan Dasar-Dasar Kimia Analitik Berbasis Problem Solving, Jurnal Pendidikan IPA Indonesia, 1 (1): 98-101.

Redhana, I. W. 2012. Model Pembelajaran Berbasis Masalah dan Pertanyaan Socratik untuk Meningkatkan Keterampilan Berpikir Kritis Siswa. Cakrawala Pendidikan, 31 (3):351-365.

Redhana, I. W \& Lilisari. 2008. Program Pembelajaran Keterampilan Berpikir Kritis pada Topik Laju Reaksi untuk 
Siswa SMA. Jurnal Forum Kependidikan, 27 (2): 103-112.

Reta, I. K. 2012. Pengaruh Model

Pembelajaran Berbasis Masalah terhadap Keterampilan Berpikir Kritis Ditinjau dari Gaya Kognitif Siswa. Jurnal Pendidikan, 26 (1): 1-16.

Saputri, Sajidan, A. C. \& Rinanto, Y. 2018. Critical thinking skills profile of senior high school students in Biology learning. International Conference on Science Education (ICoSEd): 179.61.182.168 hal. 1-6

Sudjana, N. 2013. Penilaian Hasil Belajar Mengajar. Bandung: PT Remaja Rosdakarya.

Sugiyono. 2010. Metode Penelitian

Pendidikan

(Pendekatan

Kuantitatif, Kualitatif, dan $R \& D)$. Bandung: Alfabeta.

Widana, I. W. 2017. Modul Pembuatan Soal High Order Thinking Skills (HOTS). Jakarta. Kemendikbud.

Widarti, S., E. Peniati, \& Widiyaningrum, P. 2013. Pembelajaran Gallery Walk Berpendekatan Contextual Teaching and Learning Materi Sistem Pencernaan di SMA.
Unnes Journal of Biology Education, 2 (1): 10-18.

Wijayanti, T.F., Prayitno, B.A. \& Sunarto, $\quad$ S. 2016. Pengembangan Modul Berbasis Berpikir Kritis Disertai Argument Mapping pada Materi Sistem Pernapasan untuk Meningkatkan Kemampuan Berpikir Kritis Siswa Kelas XI SMA Negeri 5 Surakarta. Jurnal Inkuiri. 5 (1): 105-111.

Wulan, A. R. 2018. Menggunakan Asesmen Kinerja untuk Pembelajaran Sains dan Penelitian. Bandung. UPI Press. 